\title{
Educating the Reflexive Practitioner
}

\author{
Marc J. Neveu, PhD Architecture Department \\ California Polytechnic State University
}

"I cannot teach anybody anything, I can only make them think."

Socrates

\section{Introduction}

Studio as a model of education is distinct from many other professional disciplines and although it can be quite rewarding on many levels it may also be an extremely unconstructive endeavor. ${ }^{1}$ The amount of time spent in studio typically far outweighs that spent for other courses and often at the expense of such other courses. The dedication that students bring to the studio is remarkable, yet much of the time spent in studio is not always productive. Students often complain of not knowing what is expected of them and as a result much of the time is spent thinking about what they think the professor wants to see as opposed to working through their projects. In an alternate scenario, students are crushed by the workload, tasks, demands or expectations of their instructors. In either case, the work is almost invariably driven by the students' own creativity and imagination; unlike law, medicine, business, or engineering for example, where the interpretation and inquiry into case studies and cadavers is much less based on the personal introspection than established traditions. This extremely personal nature of the architectural studio can make reviews either a devastating or extremely empowering process. As seen from the perspective of the larger university community, the studio is simply not an efficient way of education. The faculty to student ratio, for example, is not in accordance with other undergraduate disciplines. But this ratio, as we all know can also be a real strength. The oftenhermetic nature of the studio offers latitude for students to develop their work in relatively safe surroundings. This environment, however, may also foster the cult of personality that develops around certain professors that harkens back to the very roots of education but can also lead to an entourage of disciples who have no incentive to inform the Emperor that he or she is no longer wearing any clothes.

Notwithstanding such issues, I do believe the studio holds the potential to be an empowering learning experience. The intention of this article is to question the mode of instruction in an architectural studio. I've structured the paper in three parts. First, I will briefly describe the findings of the study made by the Carnegie Foundation for the Advancement of Teaching known as the Boyer Report. ${ }^{2}$ To develop and support the findings of the Boyer Report, I introduce the work of the educator Donald
Schön. Though I see much merit in the Boyer Report, and Schön's proposals, I argue that a more nuanced approach is required. I will recommend, therefore, in the second section of this paper that a means of architectural education as based on the Socratic method may be a more productive approach. My reading of the Socratic method is based primarily on early Socratic dialogues and I will specifically use Charmides to illustrate the issues that I believe are relevant to studio pedagogy. ${ }^{3}$ From my analysis of Charmides I will, in the third section of the essay, describe how the Socratic method is beneficial to studio pedagogy three ways: reflexive, non-propositional, and finally how Socrates' approach may indeed be practical. This last section will be illustrated with a student project. It is my conjecture that the Socratic method offers insight into current discussions of educational theory, namely student-centered, project-based learning.

\section{Boyer Report}

Published over ten years ago, the Boyer Report had two intentions. The first was to examine architecture education as it has evolved through the twentieth century. The second was to study the relationship between education and practice as well as between architecture and other disciplines. At the core of the relationship between the education of the architect and the profession was the mode of instruction in studio. The Boyer Report suggested the following.

The education of students about the scientific, social, aesthetic, political, and environmental foundations of architecture, should not be about 'teaching' disembodied skills and facts. The standards should stress active inquiry and learning by doing, rather than the accumulation of facts from texts, required lectures, or design problems handed ready-made to students. Further, students should be partners in extending the knowledge base of the profession through reflective practice. Learning to define problems, asking the right questions, and weighing alternative approaches must be at the heart of architecture study. ${ }^{4}$

We are all very aware of the phrase learn by doing, but what does it really mean and how does it relate to teaching studio? The references to learning by doing and reflective practice in the Boyer Report were surely provided by Donald Schön, the Ford Professor of Urban Studies and Education at MIT and later chair of that university's Department of Urban Studies and Planning. Schön's major study was presented in two works. The first part, the Reflective Practitioner (1983), questions the 
epistemological foundations of practice. ${ }^{5}$ It is a critique of the prevailing epistemology of practice that recognizes professional competence as the application of privileged knowledge to instrumental problems of practice.

Schön's critique of professional knowledge addresses two concerns: technical rationality and discipline-based specificity. "Technical rationality," he explains, "holds that practitioners are instrumental problem solvers who select technical means best suited to particular purposes. Rigorous professional practitioners solve well-formed instrumental problems by applying theory and technique derived from systematic, preferably scientific knowledge." ${ }^{\prime \prime}$ In this way medicine, law, business, and engineering are exemplars of professional practice for Schön in that each discipline has constructed specific and verifiable disciplinary criteria that has allowed such disciplines to operate with professional credibility. Most issues are, however, much more complicated than this. Homelessness, for example, may be seen by many different professions to be a problem, as Schön defines it, of different domains: economic, social, educational, architectural, political, etc. Each profession may support their domain with quantifiable data appropriate to their argument. A problematic situation is named, framed and therefore becomes solvable according to the domain appropriate to the particular profession. Schön is critical of this type of professional specificity, as he understands the issues that these fields purport to solve are never so simple as to be reduced to instrumental problems. Homelessness is an issue that relates equally to education, economics, and architecture, for example. Regardless, professional specificity is given precedence and authority to act. Ironically, this specificity often reduces the role of the architect to a conductor of building trades and consultants. ${ }^{7}$

In the second part of his study, Educating the Reflective Practitioner, Schön suggests that the architecture studio is an ideal model of education for professional reflective practices in which students, in partnership with their coach/professor, learn by doing. Schön describes what he perceives as a typical studio desk review and then analyzes the interaction between student and professor. He argues that the interaction demonstrated in a desk review develops a tacit knowledge that he refers to as professional artistry. It is a type of knowledge that is similar perhaps to musical improvisation or cooking in that one is able to continually re-frame the issue at hand and to imaginatively respond to changing conditions. The knowledge gained is not deductive or analytic, but rather demonstrative. This is accomplished through tactics similar to coaching in which the coach/professor demonstrates, through drawing and dialogue, how he would approach problems relating to site, program, form, scale, etc.

Schön's version of studio works well as a critique of discipline-specific technical rationality. As a proposal for an architectural studio, however, it is problematic on a number of levels. The first issue is that the student learns from the coach/professor in a passive way. There is very little evidence to show the effectiveness of a teaching model in which the student observes the professor drawing, modeling, and thinking through a project. The next critique is that Schön sees the studio only as a mirror of practice in which the professor is the more experienced and advanced designer who acts also as client by setting the criteria by which the project shall be judged. There is the illusion of a "real" project, though the reality could not be further from the truth. A studio project rarely, if ever, goes beyond very initial planning phases and almost never is a project able to be built from final drawings. ${ }^{8}$ To assume then that the same parameters exist and that the professor is able to act as both client and lead designer is dubious at best. Further, Schön's description of the relationship between the docile student and all-knowing professor (the professor is always "he," the student, "she") is fraught with old-fashioned, if not at least politically incorrect, power and gender biases. It is easy to imagine the studio described by Schön as producing disciples who do and say as the professor did and said. I would like to build upon Schön's work but propose a more nuanced approach to the dialogue between the student and the professor. To do so, I will describe the Socratic Method.

\section{Socratic Method}

The Socratic Method is characterized as a way of pedagogy by means of question and answer, distinguished from lecture-based instruction. Plato referred to Socrates dialectic as elenchus, from the cognate elenchein: to refute, to examine critically, to censure. Socrates never described his method, so to speak, nor did he make an elenchic inquiry into its nature. ${ }^{9}$ If one looks back to the earlier dialogues one finds a common manner to Socrates' inquiry. In each of the dialogues, Socrates and an interlocutor search, though never find, an answer to "What is $x$ ?" (temperance, nobility, etc). The early dialogues follow a standard pattern: an interlocutor claims knowledge of something, which is then refuted by Socrates. Gregory Vlastos has outlined a typical interaction:

1. The interlocutor, "saying what he believes," asserts $p$, which Socrates considers false, and targets for refutation.

2. Socrates obtains agreement to further premises, say $q$ and $r$, which are logically independent of $p$. The agreement is ad hoc: Socrates does not argue for $q$ or $r$.

3. Socrates argues, and the interlocutor agrees, that $q$ and $r$ entail not- $p$.

4. Thereupon Socrates claims that $p$ has been proved false, not-p true. ${ }^{10}$

In the case of Charmides, the discussion revolves around the meaning of temperance (sōphrosunē). ${ }^{11}$ The discussion begins with Socrates returning to Athens after years of service in the army. Upon his arrival, he asks about the state of Athens and if there are any youths particularly wise or beautiful. Charmides, one such beautiful and wise youth, arrives just as Socrates is asking his questions. Socrates is overwhelmed by Charmides's presence and begins to fawn over the boy. As Charmides 
is described as being temperate, Socrates presses him to define the term. Socrates compliments Charmides' ancestry in an attempt to indulge his ego. Charmides cannot agree, however, as it would reveal pride-the opposite of temperance-nor could he lie and be untrue to himself. Therefore he does the only thing he can do, he blushes. Charmides then attempts a definition. He says temperance is "good" and that it has qualities similar to "quietness" and "modesty." Socrates quickly shows both definitions to be fallacious: quietness is not good in wrestling after all; modesty is not good when one is needy. Charmides then attempts to define temperance with a borrowed definition: "doing one's own business." Socrates refutes this as well, giving the example of a craftsman who may be temperate though he often makes things for others.

It is revealed that this second definition belongs to Critias, the future tyrant and uncle to Charmides. Critias proposes and then defends his definition by making a distinction between the doing, making, and working of one's own craft. Socrates refers back to the agreed upon first part of the definition - that temperance is a "good" quality—and then expands this proposition to involve doing good both for others and for oneself, but quickly shows that people often do not know which of their actions will be beneficial in the way that they intended. Thus, it seems possible to be temperate without knowledge of the result of one's temperance. Critias objects to the suggestion that one may be temperate without knowing the effect of temperance. He then quotes the Oracle at Delphi and claims "self-knowledge" to be the definition of temperance. Socrates and Critias then decide that if temperance is a type of knowledge, then it must be a type of science. Critias suggests that temperance is a "science of a man's self." Socrates questions the effect such a science may have. Critias then accuses Socrates of simply refuting everything that is said. Socrates claims that this is the way of discussion and has nothing to do with Critias in particular. It isn't personal; rather, it is precisely how the dialogue should proceed. The two argue a bit more and then consider the conversation dead. Neither, it seems, has been able to arrive at a suitable definition or use-value for temperance. Charmides, however, has not been dissuaded by the argument and has decided that he will continue to see Socrates and pursue the true meaning of temperance.

Socrates' inquiries should not be judged for their logical rigor. He does not assert a deductive proof to conclusion; rather it is through refutation that the initial assertion by the interlocutor is put into question and an appropriate meaning is revealed. As nothing is determined with any certainty, however, one is tempted to ask what is the point of such inquiry? Gregory Vlastos has argued that the dialogues develop an objective thought, but not an objective truth. ${ }^{12}$ Leonard Nelson believes the Socratic method was not simply for instruction or content, but to instill a way of investigation..$^{13}$ Others maintain that the intention of the discussion was self-knowledge. ${ }^{14}$ Each position has consequences for architectural education. There are three characteristics that I will now elaborate upon. First, the basis of the discussion is non-propositional (in that the refutation is based in what is stated by the interlocutor and not on preconceived definitions); second, that the inquiry is reflexive (in that the content is not objectifiable as a result or separable from its method), and; third, the knowledge gained is indeed practical.

\section{Socratic Method and Studio Education}

\section{Non-propositional}

Essential to the inquiry is that Socrates privileges the topic of discussion raised by someone other than himself. He was clearly not lecturing to the youth of Athens, but rather, the conversation begins only when the interlocutor has stated a personal belief: "x." This is important for two reasons. The first is that Socrates does not name the topic. In the Charmides, it is the description of the young Charmides as temperate that begins the conversation. And secondly, this establishes a personal stake for the interlocutor who must take responsibility for their nature, actions and beliefs. Later in the dialogue, Socrates refers to Charmides as a wretch for proposing Critias' definition over the potentially more difficult but rewarding possibility of thinking on his own. Even as Charmides takes on the view of another, he is expected to defend it as his own.

This lesson of Charmides can be carried over into architecture education. Architecture students enter into school with a very real knowledge of making, of building, and of experiencing architecture. Rather than considering students as blank slates, it is important to build upon their perspective and knowledge from an early start. Socrates, however, does not allow Charmides to be content with his unreflective blush. It is essential to delve into and make specific, the intuitive understanding that students possess. Regardless of how the studio is organized, whether a programmatic approach or a more thematic inquiry, it is the responsibility of the student to develop his or her own way of working. I recently ran a studio that looked at relationships between architecture and clothing. The studio, named as studia | moda, began with fourteen trash bags of clothing and a series of exercises. After randomly selecting the bags of clothing, students were asked to take apart the clothing found in the bags and then draw the pattern of the clothing. This was intended to introduce the relationship between two-dimensional representation and a three(or even four-) dimensional article of clothing. The next exercise was to remake the deconstructed clothing into an article that students would themselves wear. Projects were varied from a corset (fashioned from an army jacket and bra) to a hockey jersey (reconstructed from a wedding dress). The third part of the exercise was to translate the new piece of clothing into a façade for the Maison Domino. These projects were completed in the first three weeks of the studio and although I set the general parameters of the studio, all of the subsequent work-including the individual development of a program-carried out during the term was based the questions and issues raised from what was made by each student. 
One student, Esther, whose project I will now discuss in more detail, entered into the studio with a self described interest in double-skin facades. Esther's bag of clothing contained thick plaid lumberjack shirt and a thin white negligee. From these two randomly selected pieces, a two-part garment was made to fit the designer: the Jack \& Jill Skirt. (Fig.1) The first part of the skirt tailors the heavy fabric into a six-paneled, mermaid-form skirt. The seams are sewn out revealing the form-giving structure. The second part of the skirt is made from the material given by the nightgown. This is gathered at the waist, so when the skirts are inverted the fullness of the gathering is set free, in a ballerina-like fluidity. A single band of lace at the waist joins the two skirts. There is a multiplicity of readings when one wears the skirt. It is both structured and rigid and also fluid and open depending upon who is wearing the garment. This multiplicity of meaning, and expansion of the dimensions of wearing is the essence of the idea that was carried into the next part of the project, the architectural translation.

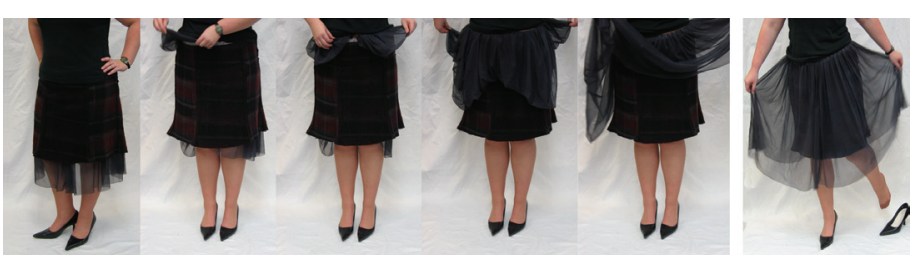

Figure 1: Jack \& Jill Skirt.

\section{Reflexive}

The essential nature of Socrates' dialectic is that it is refutive. He does not assert a preconceived premise and argue it to a conclusion; rather it is through refutation that the initial assertion by the interlocutor is put into question. Socrates' "knowledge of temperance" has content, but not as an answer or definition; the content, rather, is in the reflexivity of the dialogue. This knowledge is neither wholly subjective nor objective: true knowledge is not to be revealed solely in personal introspection (represented by Charmides' blush), or as an objectified result to be reported (Critias' sophistic definition). Meaning, therefore, is found within the process of the dialogue, within the search. Architecture, of course, is not simply a dialogue. In the way that Socrates can display temperance, one cannot exhibit "museum," for example. That distinction, notwithstanding, a professor may exhibit a way of questioning that does aim towards the specificity of intention in an architecture project. One may ask, for example, what is the nature of a museum? Is the museum for entertainment, education, collection, display, inspiration, or other? How might one display work? How might a patron interact with the work in a museum? What is the quality of light? Each of the responses has structural, material, formal, historical, situational, representational, temporal, and other implications. Following this approach and in the context of the studio, the flow of content is not top down from the professor to the student, but rather it is revealed in the conversation. What is important to recognise is that there is never one answer that is unanimously "good" or considered to be a universal truth.
Within the studio, many of the criteria that guide decisions of a professional project are, as mentioned earlier, simply not present. Because of this, new criteria need to be established by the student and professor by which the project can be developed. In the example of studia | moda, the translation of the refigured clothing into a façade for the Maison Domino offered an opportunity to frame the rules by which their individual projects would develop. Such rules, however, were not completely open. Students were required to make a translation between two modes of making that dealt with very real issues of architecture and clothing to include: the relation between the body and clothing/building, texture, tactility, program, materiality, tectonics, fabrication, joinery, etc.

Esther's interest in a double skin façade resurfaced but not only as an environmentally sensitive approach to the exterior of a building. Rather, she asked the question: What would it mean to inhabit a double skin façade surrounding the Maison Domino? The work was carried out as a series of drawings and models. (Fig.2) Through her investigations she discovered Alain Robert, a climber who, although suffering from vertigo, has free-climbed many of the world's tallest buildings. ${ }^{16}$ The interest for Esther was his ability to see a façade that was designed with a specific intention, be read in an entirely different way. She began to re-think how common everyday occurrences might be effected by shifting one's horizon ninety degrees, from horizontal to vertical. This led her to read and map the novel Flatland. Esther developed a vocabulary, specific to the issues of her project that was learned through making: through drawing, model-making, as well as speaking and writing. My role was

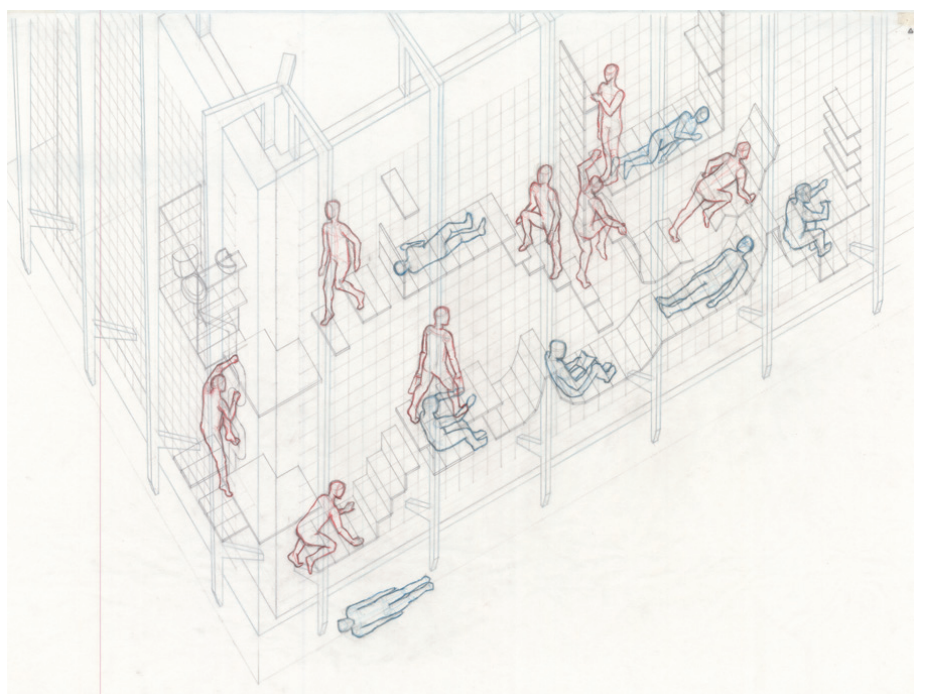

Figure 2: Inhabitable double-skin façade for the Maison Domino. 
not name the specific method of inquiry or the issues within the facade, but to question and encourage Esther and each of the other students to critically look at what they had made and then begin to develop such issues into an architectural project. In this way, the students developed a similar, rigorous and iterative, way of questioning his or her own work that was grounded in an open dialogue with historical precedent and technical performance.

\section{Practical}

The third and final characteristic of the Socratic method is that it is practical. Socrates' elenchic search for the thing-ness of things was essentially focused on self-understanding. I contend that self-knowledge is understood in the way one inquires. As the Socratic Scholar, Thomas Schmid has pointed out, "The Socratic dialect challenges him (the interlocutor) not only to acquire the correct moral opinions but to question himself and think for himself and develop his own moral rationality." ${ }^{17}$ In this way, the work in studio is not simply for instruction or content, but to instill a way of investigation. It is this type of knowledge that I would call practical. It is a knowledge that cannot be passed on like dates or figures, similar to water in a vessel. But it is knowledge, found through making and is exhibited in practice. It is a type of knowledge, similar to that attained by Socrates' elenchic that is found in action; knowledge gained by making. To put the discussion back into the studio, one may say that similar deep knowledge should be the goal and this is found through drawing, modeling, through architectur-ing.

The program that Esther developed-a Youth Hostel on the Sunset Strip in Los Angeles-achieved this level of inquiry. (Fig. 3) After the initial studies students travelled to Los Angeles and visited the site: any piece of the Sunset Strip. While documenting the Strip, Esther found an open lot where billboards were constructed and saw that a homeless man was living in one of the tubular structural supports. There was an uncanny appropriateness between what was happening on the site and the work she had begun developing through her façade studies. The project required a complete cataloguing of the on-site materials and the construction details showing connection methods for the lightweight steel frames, which created a basis for understanding the given structures. This opened the possibility of posing the questions of adaptive re-use, shifting perspectives of space, and the potential inhabitation through modification of a narrow volume. The billboard, often dismissed as a blatant commercial presence imposing on the public realm, is not simply the two dimensional image on display, but has a thickness, a hidden structure in support of the surface. Esther documented each type of billboard on the site and then developed an appropriate program for each. The vertical/portrait billboard was configured into shared shower and bathrooms. (Fig. 4) The height of the advertising boards was enough to give four eight-foot high spaces, accounting for floor thickness between them. In effect, this design creates four small rooms, stacked adjacent to the vertical stack. These rooms are just enough space to

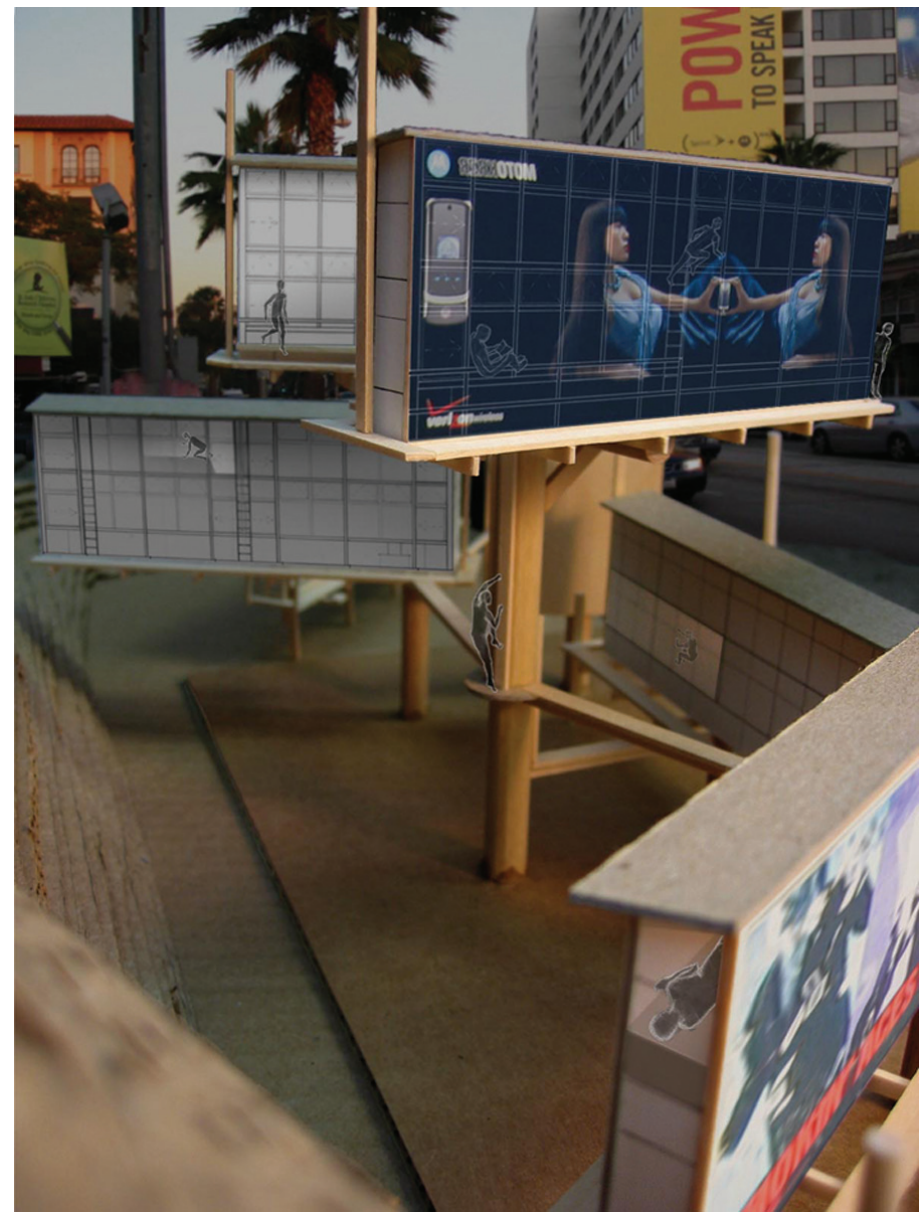

Figure 3: Sunset Strip Youth Hostel, model view during the day.

create two shower rooms, and two washrooms with basins. Each room is enclosed with a lockable, bi-fold door, and is accessed by a ladder and series of platforms at each floor level. The plumbing passes through the vertical cylinder stack and is reinforced with shop-welded reinforcing collars. The structural integrity of the cylinder was preserved even with the new active and dead loads. The other side of the billboard holds the hot-water tank, solar pre-heating coils on the exposed face, and a series of gray water storages tanks. The water from the showers above is held in a tank to flush the toilets below. This level of detail was explored for each of the other building types. As with the previous project, she rethought how one might live, sleep, bathe, and eat within the thickness of a billboard. She also considered the potential for the hostel to still act a mechanism for advertising. In my opinion, the project was successful not for the final form achieved, but for the manner in which Esther carried out her inquiry. The somewhat unbelievable program-a youth hostel within a series of billboards-was developed through a series of very believable representations. 


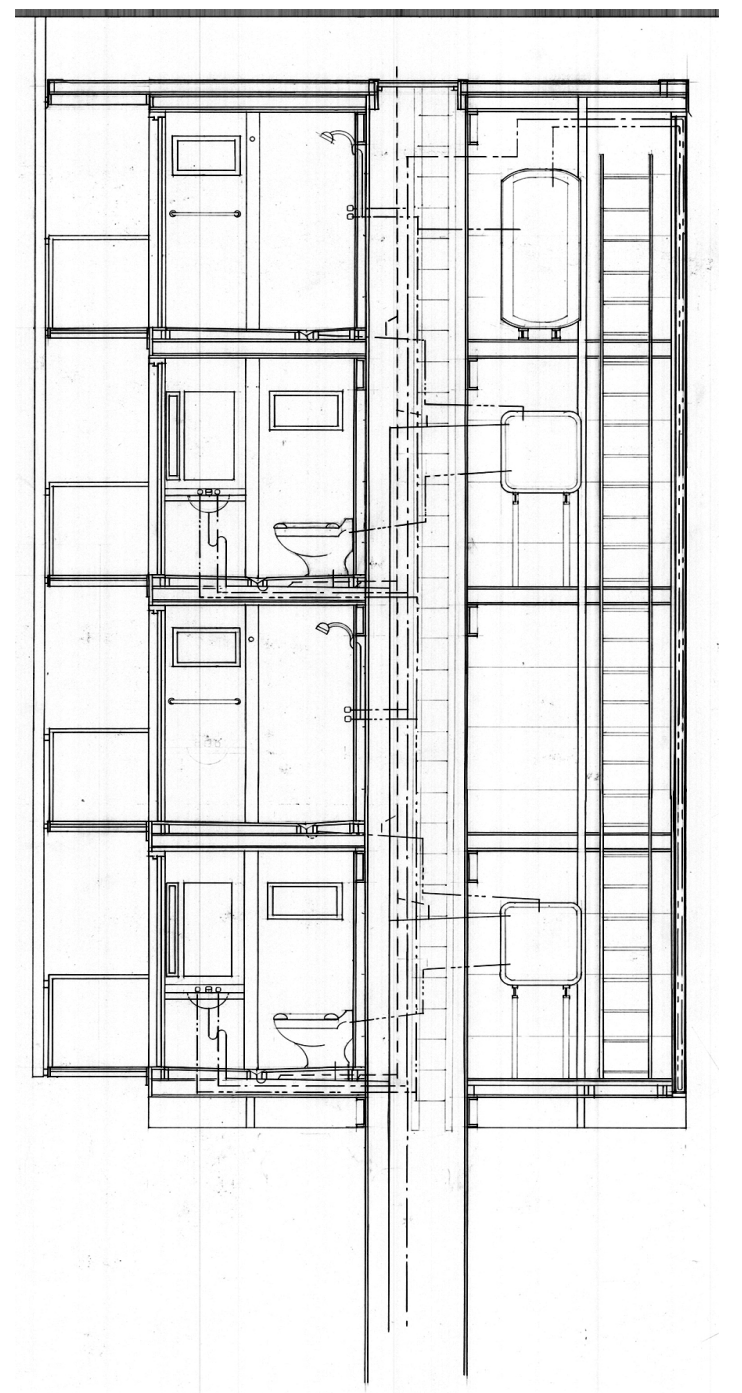

Figure 4: Shared bath component of the Sunset Strip Youth Hostel.

\section{Conclusion}

I have described the Socratic method as a model for the mode of instruction within a studio. Although the approach is two millennia old, there are definite affinities with contemporary pedagogic theories that emphasize student-centered, problem-based learning. An architectural studio offers an ideal situation for problem-based learning and is indeed often seen as a model for other disciplines. A problem-based approach is not enough however. It is essential that students feel as if they have a choice in the decisions being made and have a stake and responsibility in what is being learned. Lea et al. have summarized the main tenets of student-centered learning to include:
- Reliance on Active rather than Passive learning,

- Emphasis on deep learning and understanding,

- Increased responsibility and accountability on the part of the student,

- An increased sense of autonomy of the learner,

- Mutual respect within the learner teacher relationship,

- And a reflexive approach to the teaching and learning process on the part of both teacher and learner.

This approach supports Schön's understanding of the professional as one who is able to solve well-formed problems. In this way, architecture is certainly a "reflective practice," but I would argue that the knowledge gained from the Socratic method leads to a reflexive practice in that it reveals a world rather than proves a solution. There is an exhibited specificity in such inquiry but not a specificity that relates to established domains or technical expertise. Rather, professional precedence and authority to act are given by the opening up to the complexity of our lived experience. In this way, the value of the work is not in a definitive answer or final project, but rather it is in the non-propositional knowledge acquired through open inquiry with the world. In this way, an architectural education may prepare a student for many paths; as a developer, as a contractor, as a sculptor, and certainly for work in an architectural office. Finally, I would propose that the value of an architecture education lies in the ability of the student to become professional in that they are enabled to take responsibility for their own education and begin a career of life-long learning. It is their task to develop and name their own questions. Once the student has stated something in which she or he believes, it is possible to question and develop what that might mean. This mode of instruction, then may be characterized as maieutic, in that it implies a way of teaching that urges a student to become aware of ideas latent in their own experience. Further, this encourages students to take responsibility for their own beliefs and indeed, their education. The task of the professor, then, is to develop a way of questioning within the student, which is analogous to the examined life: the only life, according to Socrates, worth living.

\section{Endnotes}

1 There are many studies that address the studio as an unconstructive learning environment. Leonard and Christine Bachman "Student Perceptions of Academic Workload in Architectural Education." Journal of Architectural and Planning Research, 23 (4), 271-304 devised a metric by which a balance between stress and productivity could be maintained. The article also includes an informative bibliography.

2 Boyer, Ernest and Lee Mitgang. Building Community: A New Future for Architectural Education and Practice. (Princeton, N.J.: Carnegie Foundation for the Advancement of Teaching, 1996).

3 Charmides, Ed. and Trans. W. R. M. Lamb, Loeb Classical Library 201 (Cambridge, MA: Harvard University Press, 1964).

4 Boyer, Ernest and Lee Mitgang. Building Community: A New Future for Architectural Education and Practice. (Princeton, N.J.: Carnegie Foundation for the Advancement of Teaching, 1996): 72. 
5 Schön, Donald. the Reflective Practitioner. (New York: Basic Books, 1983).

6 Schön, Donald Educating the Reflective Practitioner. (San Francisco: Jossey-

Bass, 1983): 3.

7 The lack of professional authority is made painfully clear when one looks to the insignificant percentage of buildings actually designed by Architects in North America. Further, Architects have very little, if any, legal protection of our professional authority. In most states, for example, Structural and Civil Engineers are able to build any type of building.

8 Indeed, there are many differences between the studio and an office environment to include: lack of client negotiations, funding issues, consultant relationships, time constraints, as well as the economic reality of running an office.

9 Plato only names it as such in the middle dialogues, specifically the Republic.

10 Vlastos, Gregory. "The Socratic Elenchus" Journal of Philosophy, vol.79 no. 11 (Nov.,1982), 712.

11 Charmides, Ed. and Trans. W. R. M. Lamb, Loeb Classical Library 201 (Cambridge, MA: Harvard University Press, 1964): 45.

12 See Gregory Vlastos, "The Socratic Elenchus." Oxford Studies in Ancient Philosophy. Ed. Julia Annas (Oxford: Clarendon Press), 27-74.

13 See Leonard Nelson, Socratic Method and Critical Philosophy, Selected Essays. Tr. Thomas K. Brown III (New Haven: Yale UPress, 1949).

14 See Sara Rappe, "Socrates and Self-Knowledge." Aperion Vol. 28 (1995), 1-24 and also Julia Annas, "Self-Knowledge in Early Plato." Studies in Philosophy and the History of Philosophy. Vol. 13 Ed. Dominic J O'Meara (1985), 111-38.

15 The studio was a vertical studio composed of architecture students in the final year of an Environmental Design degree and those in the first two years of professional M.Arch program at the University of Manitoba in Winnipeg, Manitoba.

16 See Robert, Alain. With Bare Hands: The True Story of Alain Robert, the Real-life Spiderman. (Blacksmith Books: Hong Kong, 2008). Esther was also inspired by Alex Hartley's LA Climbs: Alternative Uses for Architecture. (Black Dog Publishing: Los Angeles, 2004) in which the author describes ways to climb many iconic buildings in Los Angeles. As with Robert, the interest for Esther, was in the ability to perceive architecture in other ways.

17 W. Thomas Schmid, "Socratic Dialectic in the Charmides." Does Socrates Have a Method? Rethinking the Elenchus in Plato's Dialogues and Beyond. Ed. Gary Allen Scott (University Park: Pennsylvania State UPress, 2002): 240.

18 Student-based learning is a relatively new phrase in pedagogic theory, but it is clear that previous educational theorists, specifically Froebel, Dewey, Piaget, and others, have developed such approaches. For discussion of the history of Student-based learning, see: Geraldine O'Neill and Tim McMahon "StudentCentered Learning: What does it Mean for Students and Lecturers?" Emerging Issues in the Practice of Teaching and Learning. Eds. Geraldine O'Neil, G, Moore, S. McMullin, (Dublin: AISHE, 2005): 27-36. The shift to a more studentcentered learning can also be seen in curricular changes. MIT, for example, has recently reworked freshman level lectures to become problem-based workshops that offer a more collaborative learning experience. See Sara Rimer, "At M.I.T., Large Lectures Are Going the Way of the Blackboard" New York Times 12 Jan 2009. The article describes similar initiatives at other universities.

19 Lea, S.J., D. Stephenson, and J. Troy. "Higher Education Students' Attitudes to Student Centered Learning: Beyond Educational Bulimia." Studies in Higher Education. 23 (3,2003), 321-334. 